\title{
Prediksi Curah Hujan Menggunakan Gerak Brown dan Rataan Tahunan Data Pada Missing Values
}

\author{
Nur Nining Aulia ${ }^{\# 1}$, P. H. Gunawan ${ }^{\# 2}$, Aniq Atiqi Rohmawati ${ }^{\# 3}$ \\ \# School of Computing, Universitas Telkom \\ Jalan Telekomunikasi No. 1 Terusan Buah Batu, Bandung 40257, Indonesia \\ ${ }^{1}$ ningaul@ student.telkomuniversity.ac.id \\ ${ }^{2}$ phgunawan@telkomuniversity.ac.id \\ 3 aniqatiqi@ telkomuniversity.ac.id
}

\begin{abstract}
Rainfall can give the positive and negative impacts for the living organisms in earth. One of the negative impact posed is flooding, while the positive impact of technology is hydroelectric power source. Therefore to maximize the positive impact and minimize the negative impact of rainfall then prediction of rainfall is required. In this paper, rainfall prediction is conducted by Monte Carlo method with Brown motion where the data used is the rainfall data from BMKG with the total data of 1461 data from 1 January 2014 to 31 December 2017. Before predicting rainfall, the mean and volatility in the data is normalized to avoid the effect of certain anomaly data. Here, predictions have done as much as by using 10, 50, 100, 150 and 200 times iterations. In the iteration of 200, Root Mean Square Error value for four stations are obtained 20.6875, 13.9811. 20.6112 and 20.293 respectively in sequence.
\end{abstract}

Keywords: Brownian Motion, Monte Carlo, Mean, Normalization, Root Mean Square Error and Volatility.

\begin{abstract}
Abstrak
Air hujan yang turun dapat menimbulkan dampak negatif dan positif ke berbagai makhluk hidup yang ada di bumi. Salah satu dampak negatif yang ditimbulkan adalah banjir, sedangkan dampak positif yang ditimbulkan pada bidang teknologi adalah sebagai sumber listrik tenaga air. Sehingga untuk memaksimalkan dampak positif dan meminimalkan dampak negatif dari curah hujan maka dilakukan prediksi. Pada jurnal ini dilakukan prediksi curah hujan dengan menggunakan metode Monte Carlo dengan Gerak Brown dimana data yang digunakan adalah data curah ujan dari BMKG dengan jumlah data sebanyak 1461 data terhitung dari tanggal 1 Januari 2014 hingga 31Desember 2017. Sebelum memprediksi curah hujan terlebih dahulu menghitung rata-rata dan volatilitas pada data yang telah di normalisasi. Prediksi dilakukan sebanyak 10,50, 100, 150 dan 200 kali iterasi. Pada iterasi-200 didapatkan nilai Root Mean Square Error sebesar 20.6875, 13.9811, 20.6112 dan 20.293 untuk masing-masing empat stasiun secara berurutan.
\end{abstract}

Kata Kunci: Curah hujan, Gerak Brown, Monte Carlo, Return, Root Mean Square Error dan Volatilitas.

\section{Pendahuluan}

U URAH hujan merupakan salah satu faktor terpenting dalam kehidupan. Sebab banyak bidang kehidupan yang sangat memerlukan curah hujan, misalnya di bidang pertanian, industri dan juga 
Nur Nining A. ET.AL.

Prediksi Curah Hujan menggunakan...

teknologi. Pada bidang pertanian curah hujan digunakan untuk meningkatkan produksi tani, sedangkan dibidang teknologi curah hujan dapat digunakan sebagai pembangkit listrik tenaga air. Disamping adanya dampak positif dari curah hujan, tentu saja dapat menimbulkan dampak negatif misalnya bencana alam seperti longsor, banjir dan juga kekeringan. Sehingga untuk mengatasi bencana alam yang akan terjadi dan juga untuk mengoptimalkan kinerja produktivitas teknologi dan industri maka sebaiknya mengetahui curah hujan yang akan datang dalam waktu terdekat. Untuk mengetahui curah hujan kedepannya maka dilakukan prediksi [5]. Prediksi pada dasarnya merupakan dugaan mengenai terjadinya suatu kejadian atau peristiwa di waktu yang akan datang. Prediksi bisa bersifat kualitatif (tidak berbentuk angka) maupun kuantitatif (berbentuk angka) [5]. Secara kuantitatif Ada dua cara untuk memprediksi curah hujan yakni [10] :

1) Dengan melibatkan faktor lain yang menyebabkan curah hujan Pendekatan pertama dengan melibatkan faktor lain yang mengakibatkan curah hujan. Namun,dengan menggunakan pendekatan ini terdapat beberapa hambatan untuk memprediksi curah hujan antara lain :

a) Curah hujan adalah sistem dinamik yang kompleks yang bervariasi baik di ruang dan waktu

b) Bahkan jika proses curah hujan dapat disederhanakan secara ringkas, namun terdapat kendala saat dalam perhitungan jumlahnya.

c) Data yang tersedia seperti kecepatan angin,intensitas curah hujan terbatas

2) Dengan menggunakan data sebelumnya

Pendekatan kedua terhadap peramalan curah hujan adalah dengan menggunakan data curah hujan sebelumnya (data historis).

Banyak metode yang dapat digunakan untuk memperoleh prediksi curah hujan, baik dengan menggunakan pendekatan dengan melibatkan faktor lain yang menyebabkan curah hujan ataupun dengan menggunakan data histori. Adapun beberapa metode yang digunakan untuk memprediksi curah hujan berkaitan dengan variabel lain yakni metode regresi linier dan ARIMA.

Metode regresi linier adalah metode yang memprediksi berdasarkan variabel-variabel lain yang menyebabkan curah hujan. Kualitas dari metode ini bergantung terhadap data training apabila persebaran data tidak merata maka model yang dihasilkan tidak akurat. Penelitian tentang prediksi menggunakan model prediksi linier yang pernah dilakukan salah satunya adalah "application to Indian monsoon rainfall prediction by artificial neural networks and multiple linear regression models" untuk memprediksi curah hujan monsun India dengan menggunakan jaringan saraf tiruan dan model regresi linier berganda [3].

ARIMA merupakan metode yang berdasar pada konsep regresi liner dimana memiliki tingkat akurasi yang sangat baik terhadap prediksi jangka pendek akan tetapi akurasi kurang baik saat prediksi jangka panjang. Penelitian tentang prediksi menggunakan model ARIMA yang pernah dilakukan salah satunya adalah "Perbandingan ARIMA untuk prediksi curah hujan" penelitian tersebut dilakukan untuk memprediksi curah hujan bulanan di daerah Semarang menggunakan ARIMA [11].

Jika menggunakan data histori dapat dilakukan dengan metode Moving Average dan metode Monte Carlo. Metode Moving Average adalah metode yang memprediksi suatu nilai pada priode mendatang berdasarkan nilai rata-rata suatu nilai. Adapun kerugian dari Moving Average adalah apabila data mengalami perubahan drastis maka hasil prediksi yang diperoleh kurang baik, jika data mempunyai suatu trend maka metode ini kurang baik untuk digunakan dan data setiap tahun diberi bobot yang sama. Simulasi metode Monte Carlo merupakan bentuk simulasi dimana solusi dari suatu masalah yang diberikan berdasarkan randomisasi (acak) serta menghitung nilai probabilitasnya dengan tujuan menentukan nilai yang baik berdasarkan distribusi data yang digunakan.

Kelebihan dari metode Monte Carlo dibandingkan dengan metode lainnya adalah semakin banyak simulasi yang dilakukan maka hasil prediksi yang dilakukan semakin konvergen [6]. Namun, simulasi metode Monte Carlo memiliki kekurangan yakni memiliki range yang luas, sehingga untuk membatasi range dari Monte Carlo maka digunakan Gerak Brown. Pada penulisan ini akan dilakukan perediksi curah hujan dengan menggunakan metode Monte Carlo dengan Gerak Brown yang memanfaatkan data histori curah hujan di wilayah Sulawesi Selatan. 


\section{Tinjauan Pustaka}

\section{A. Normalisasi}

Normalisasi adalah proses memetakan data sehingga menjadi nilai yang berada pada interval nol hingga satu dengan tujuan agar data menjadi singkron [8], [17]. Untuk menentukan nilai normalisasi maka dapat dilakukan dengan persamaan (1) dimana nilai $R_{i}$ adalah nilai normalisasi dan ch adalah curah hujan.

$$
R_{i}=\left(\frac{\operatorname{ch}(i)-\min (\operatorname{ch})}{\max (\operatorname{ch})-\min (\operatorname{ch})}\right)
$$

Setelah mendapatkan nilai $R_{i}$ maka dengan persamaan (2) dapat menentukan nilai rata-rata dari $R_{i}$ yang disimbolkan $R_{\text {rata }}$ dan $n$ merupakan banyak data.

$$
R_{\text {rata }}=\frac{\sum_{i=1}^{n} R_{i}}{n}
$$

\section{B. Volatilitas}

Volatilitas merupakan besar fluktasi dari data curah hujan yang diukur dengan menggunakan standar deviansi, apabila nilai volatilitasnya tinggi berarti curah hujan berubah (naik dan turun) dengan range yang besar, sedangkan jika nilai volatilitas rendah maka curah hujan cenderung konstan [13]. Untuk mengukur nilai volatilitas maka dapat digunakan dengan persamaan (3)

$$
\sigma=\sqrt{\frac{\sum_{i=1}^{n}\left(R_{i}-R_{\text {rata }}\right)^{2}}{n-1}}
$$

\section{Monte Carlo}

Metode Monte Carlo merupakan algoritma komputasi yang bertujuan untuk mensimulasikan perilaku sistem fisik, matematika dan statistik [7]. Metode Monte Carlo adalah metode untuk menaksir suatu nilai yang tidak dapat di tentukan secara analitik. Untuk menentukan nilai tersebut maka dilakukan penaksiran secara numerik dengan melibatkan sampel percobaan bilangan acak. Bilangan acak digunakan untuk menjelaskan kejadian acak setiap waktu dari variabel acak dan secara berurutan mengikuti setiap perubahan yang terjadi dalam proses simulasi [2]. Adapun kelebihan dari Monte Carlo yakni semakin banyak percobaan yang dilakukan maka solusi yang diperoleh semakin konvergen.

\section{Random Walk}

RandomWalk adalah sebuah teori probabilitas yang menyatakan sebuah data yang bersifat random. Data yang ada menunjukkan pergerakan yang tidak beraturan (random), dengan probabilitas untuk bergerak naik dan turun adalah sama [14]. Seperti yang di ilustrasikan pada gambar (1) pergerakan RandomWalk diibaratkan seperti orang mabuk yang bergerak random dan tidak beraturan.
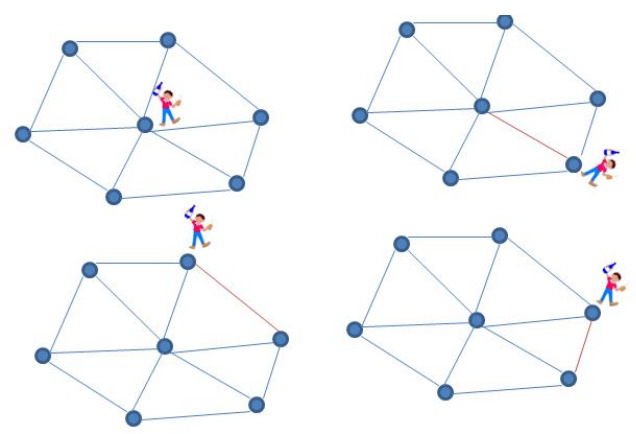

Gambar 1: Ilustrasi Random Walk 
Nur Nining A. ET.AL.

Prediksi Curah Hujan menggunakan...

\section{E. Gerak Brown}

Gerak Brown atau biasa disebut proses Wiener merupakan proses stokastik yang bersifat kontinu dan memiliki batas luas dan panjang tertentu. Gerak Brown memiliki prinsip kerja hampir sama dengan rantai markov yakni untuk memodelkan nilai prediksi tergantung pada kuantitas nilai sekarang [12]. Selain bersifat kontinu Gerak Brown juga merupakan proses stokastik yang paling sederhana sehingga Gerak Brown terus dikembangkan. Salah satu bentuk perkembangan Gerak Brown yang sering digunaka yakni Geometrik Gerak Brown yang dapat digunakan untuk mencari model pergerakan data dimasa mendatang [16].

\section{Hubungan Monte Carlo dengan Gerak Brown}

Metode Monte Carlo dan metode Gerak Brown merupakan metode probalistik yang memiliki persamaan yakni digunakan untuk memprediksi suatu angka random (acak) tetapi perbedaan yaitu terletak pada rangenya. Metode Monte Carlo merupkan metode prediksi yang memiliki range yang luas sedangkan Gerak Brown memiliki range yang sempit yang dibatasi oleh luas dan panjang tertentu [9]. Sehingga, untuk memprediksi nilai curah hujan kedapannya menggunakan metode Monte Carlo yang rangenya di perkecil oleh Gerak Brown.

\section{F. Simulasi Geometris Gerak Brown}

Geometrik Gerak Brown merupakan perkembangan dari Gerak Brown yang memanfaatkan teori Kalkulus, Stokasitik dan Persamaan Lemma Ito untuk mendapatkan variabel-variabel acak. Bila diasumsikan $c h_{\text {old }}$ adalah curah hujan pada waktu $t-i$ kemudian $d t$ merupakan waktu dari curah hujan misalnya satu hari lalu dan $d c h$ adalah perubahaan curah hujan. Maka persamaan (4) merupakan persamaan dari Geometrik Gerak Brown [7].

$$
\frac{d c h(i)}{\operatorname{ch}(d, i-1)}=\mu d t+\sigma d W
$$

Dimana $d W$ merupakan Gerak Brown acak lalu $\mu$ adalah mean dan $\sigma$ merupakan nilai volalitas dari data yang telah di normalisasi. Jika curah hujan dapat diprediksi tanpa memerlukan kondisi acak (Gerak Brown) $d W=0$ maka di akan dapatkan persamaan (5)

$$
\frac{d c h(i)}{\mu d t}=\operatorname{ch}_{\text {old }(i-1)}
$$

Untuk mensimulasikan persamaan (5) maka diambil dari distribusi normal $d w$ dengan menggunakan persamaan (6) untuk menghitung $d c h(\mathrm{i})$ dan memperoleh nilai $c h_{n e w}$ yang merupakan nilai curah hujan baru. Dengan rata-rata $d W$ adalah nol dan variansinya bergantung pada ukuran dari $d t$. Maka $d W$ dapat diganti dengan $\sigma \sqrt{d t} N$ [4], [15], sehingga didapatkan persamaan (7) .

$$
\begin{aligned}
c h_{\text {new }(i)} & =\operatorname{ch}_{\text {old }(i-1)}+d \operatorname{ch}(i) . \\
\frac{d c h}{c h} & =\mu d t+\sigma \sqrt{d t} N
\end{aligned}
$$

Untuk menghitung $d c h(i)$ digunakan dengan persamaan (9)

$$
d \operatorname{ch}(i)=\operatorname{ch}_{\text {old }(i-1)}(\mu d t+\sigma \sqrt{d t} N)
$$

Dengan mensubtitusikan persamaan (6) dan pada persamaan (9) maka diperoleh persamaan (9) untuk menentukan nilai $c h_{n e w(i)}$

$$
c h_{n e w(i)}=\left(\operatorname{ch}_{\text {old }(i-1)}(\mu d t+\sigma \sqrt{d t} N)\right)+\operatorname{ch} \text { old (i-1) }
$$

Dimana diketahuin $\mathrm{N}$ adalah peubah acak distibusi normal dengan mean 0 dan variansi 1 , $c h_{n e w}$ curah hujan terbaru dan $\sqrt{d t}$ adalah bentuk diskrit Brown. 


\section{G. RMSE (Root Mean Square Error)}

RMSE adalah salah satu metode yang sering digunakan untuk mengkur keakuratan suatu model. RMSE merupakan salah satu cara untuk mengkur nilai kesalahan dalam prediksi dimana, suatu indikator kesalahannya didasarkan pada total kuadratis dari simpangan antara hasil model dengan data aktual. Dengan menggunakan persamaan (10) dapat menghitung nilai RMSE dimana $c h_{i}$ merupakan data aktual pada waktu ke $p$ dan $c \hat{h}_{i}$ merupakan nilai prediksi pada waktu ke $p$ dan $n$ merupakan jumlah observasi.

$$
R M S E=\sqrt{\frac{\sum_{i=1}^{n}\left(c h_{i}-c \hat{h}_{i}\right)^{2}}{n}}
$$

\section{Metode PENELITIAN}

Perancangan sistem prediksi curah hujan menggunakan metode Monte Carlo dengan gerak brown mengikuti flowchart pada gambar (2) dimana :

1) Data

Data curah hujan dari BMKG yang terdiri dari empat stasiun yakni stasiun Klimatologi Maros, stasiun Meteorologi Pongtiku, stasiun Meteorologi Andi Jemma dan stasiun Geofisika Gowa dengan jumlah data masing-masing 1461 data terhitung dari tanggal 1 Januari 2014 hingga 31 Desember 2017.

2) Mengisi missing value

Pada data terdapat missing value yang berarti kosongnya nilai pada data tersebut. Untuk mengisi missing value pada data maka dilakukan preprocessing data sehingga mendapatkan nilai untuk mengisi missing value.

3) Normalisasi

Data diproses sehingga menghasilkan nilai yang berada pada rentang nol hingga satu.

4) Mean dan volatilitas

Perhitungan mean dan volatilitas dari data yang telah dinormalisasi yang digunakan sebagai parameter untuk memprediksi curah hujan dengan menggunakan metode Monte Carlo dengan Gerak Brown.

5) Input parameter

Mengimput nilai parameter yang diperlukan untuk memprediksi nilai Curah hujan kedepannya. Parameter yang diperlukan seperti nilai $\sigma, \mu, S_{0}, p$, nhari dan $d t$.

6) Prediksi data dengan menggunakan Monte Carlo dengan Gerak Brown

Memprediksi curah hujan dengan menggunakan metode Monte Carlo dan Gerak Brown dengan menggunakan persamaan (9)

7) RMSE

Menghitung nilai RMSE dilakukan dengan membandingkan prediksi curah hujan dengan data aktual curah hujan dengan menggunakan persamaan (10) 
Nur Nining A. ET. AL.

Prediksi Curah Hujan menggunakan...

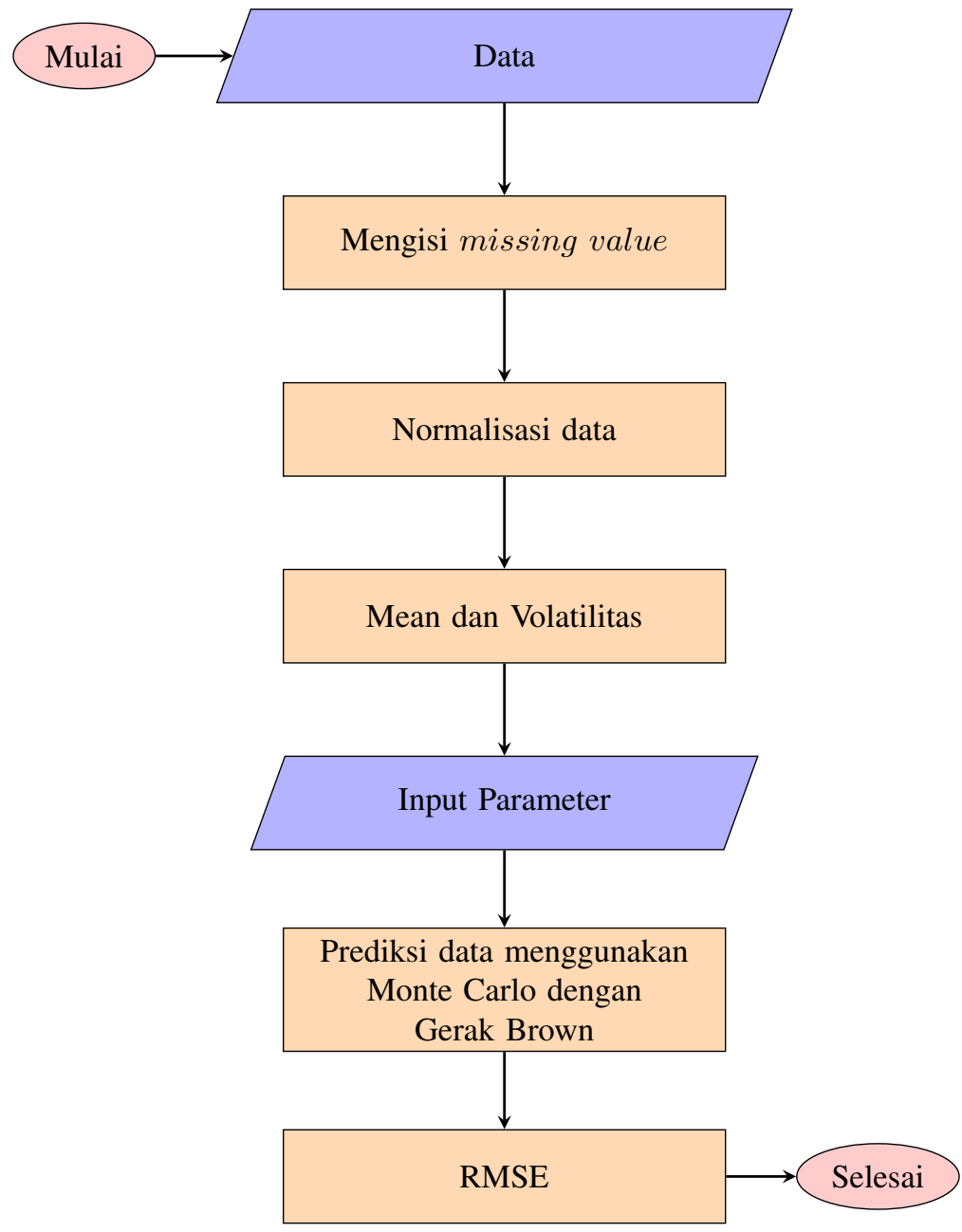

Gambar 2: Flowchart Prediksi Curah Hujan

\section{HASIL DAN DISKUSI}

Pada tahap ini akan menjelaskan bagaimana langkah-langkah untuk mengisi missing value, menghitung mean dan volatilitas pada data yang telah di normalisasi, estimasi parameter yang digunakan untuk memprediksi curah hujan dan menghitung RMSE.

\section{A. Preprocessing Data}

Data yang digunakan terdiri dari lima stasiun dengan jumlah missing value yang berbeda. Adapun jumlah missing value pada data tersebut di tunjukkan pada tabel (I) dengan [1]. Pengisian missing value dilakukan dengan cara mengambil rata-rata atas dan bawah pada data. Misalnya untuk data pada tanggal 12 Januari 2016 adalah missing value maka untuk mengisi missing value tersebut dilakukan dengan cara menjumlahkan data pada tanggal 11 Januari 2016 dan 13 Januari 2016 kemudian menghitung rata-ratanya. 
Tabel I: Jumlah Missing Value Pada Data Curah Hujan Setiap Stasiun

\begin{tabular}{|l|l|l|}
\hline No & Stasiun & Missing Value \\
\hline 1 & Stasiun Klimatologi Maros & 688 \\
\hline 2 & Stasiun Meteorologi Pongtiku & 531 \\
\hline 3 & Stasiun Meteorologi Andi Jemma & 420 \\
\hline 4 & Stasiun Geofisika Gowa & 265 \\
\hline
\end{tabular}

\section{B. Statistika Deskriptif Curah Hujan}

Statistika Deskriptif Curah Hujan menampilkan rata-rata, nilai maksimum, minimum, standar deviansi dan variansi setiap stasiun. Bila stasiun 1 adalah stasiun Klimatologi Maros, stasiun 2 adalah stasiun Meteorologi Pongtiku, stasiun 3 adalah stasiun Meteorologi Andi Jemma dan stasiun 4 adalah stasiun Geofisika Gowa maka statistika deskriptif curah hujan dapat dilihat pada tabel (II).

Tabel II: Tabel Statistika Deskriptif Curah Hujan Pada Setiap Stasiun Dimana Untuk Mengisi Missing Value Menggunakan Rata-Rata Seluruh Data

\begin{tabular}{|l|l|l|l|l|l|}
\hline Stasiun & Mean & Max & Min & Sdv & Var \\
\hline 1 & 12.2884 & 156 & 0.0001 & 18.3528 & 336.5939 \\
\hline 2 & 7.9122 & 91 & 0.0001 & 11.3122 & 127.8791 \\
\hline 3 & 10.6961 & 133 & 0.0001 & 16.1228 & 259.768 \\
\hline 4 & 8.9699 & 206 & 0.0001 & 17.8854 & 319.6675 \\
\hline
\end{tabular}

\section{Histogram Data}

Tujuan menampilkan histogram dari setiap stasiun yakni untuk melihat frekuensi terbesar dari setiap data. Gambar (3) merupakan histogram dari semua stasiun dimana sumbu x merupakan nilai curah hujan dan sumbu y merupakan frekuensi data. Frekuensi data terbesar pada gambar (3a), (3b), (3c) dan (3d) berada di curah hujan yang kecil yakni dan frekuensi terkecil berada di curah hujan yang besar adalah pada setiap data.

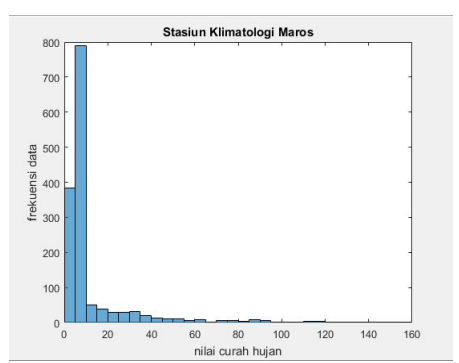

(a)

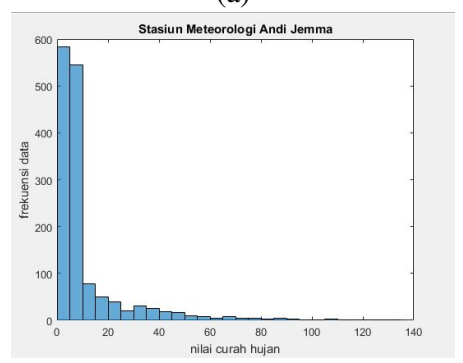

(c)

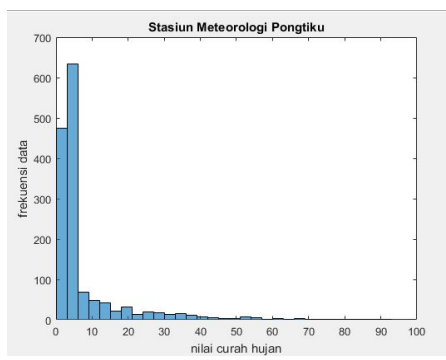

(b)

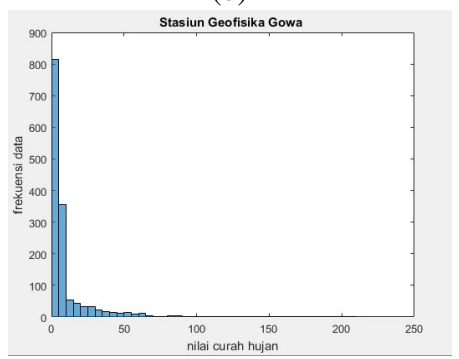

(d)

Gambar 3: Histogram Curah Hujan Pada Semua Stasiun. Gambar (3a) adalah histogram curah hujan stasiun Klimatologi Maros, gambar (3b) adalah histogram curah hujan stasiun Meteorologi Pongtiku, gambar (3c) adalah histogram curah hujan stasiun Meteorologi Andi Jemma, gambar (3d) adalah histogram curah hujan Stasiun Geofisika Gowa 
Nur Nining A. ET.AL.

Prediksi Curah Hujan menggunakan...

\section{Normalisasi}

Normalisasi merupakan proses memetakan data sehingga menjadi nilai yang berada pada rentang nol hingga satu. Untuk melakukan normalisasi maka diperlukan histori data dari masing-masing stasiun sebagai input. Dengan menggunakan persamaan (1) maka akan diperoleh data normalisasi dengan plot seperti pada gambar (4) masing-masing data telah berada pada interval 0 sampai 1. Pada gambar (4) merupakan plot dari semua stasiun dimana sumbu x merupakan nilai curah hujan yang telah di normalisasi dan sumbu y waktu dalam satuan hari.

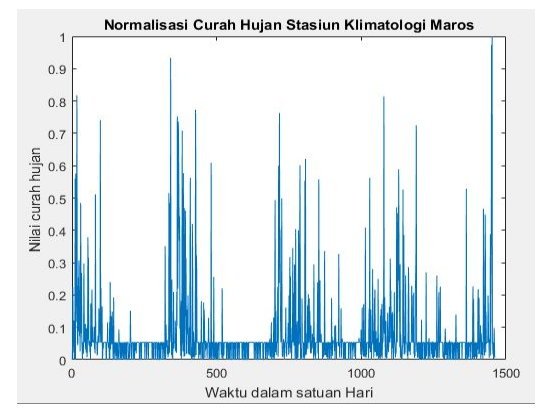

(a)

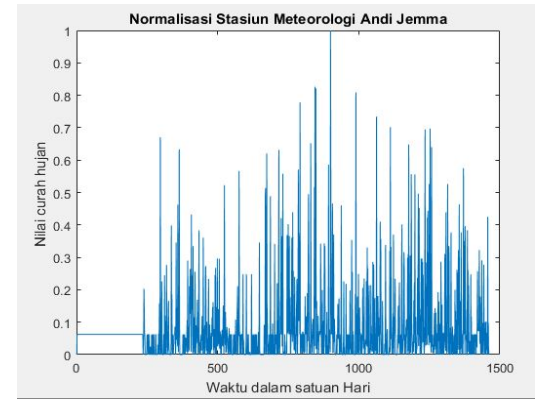

(c)

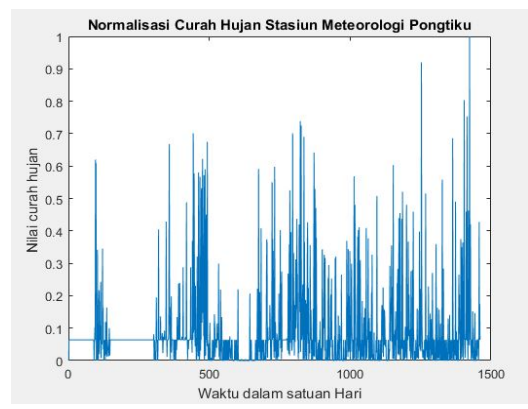

(b)

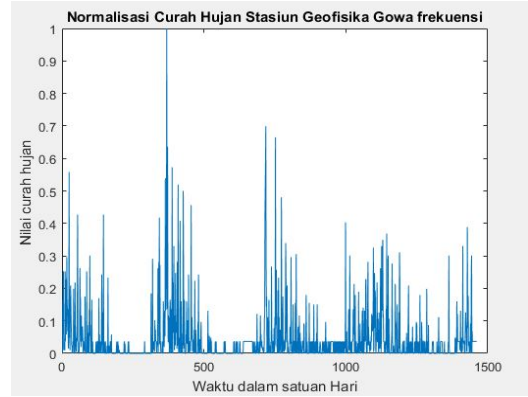

(d)

Gambar 4: Normalisasi Curah Hujan Pada Semua Stasiun. Gambar (4a) adalah normalisasi curah hujan stasiun Klimatologi Maros, gambar (4b) adalah normalisasi curah hujan stasiun Meteorologi Pongtiku, gambar (4c) adalah normalisasi curah hujan stasiun Meteorologi Andi Jemma, gambar (4d) adalah normalisasi curah hujan Stasiun Geofisika Gowa

\section{E. Prediksi Curah Hujan}

Setelah melakukan normalisasi pada data kemudian menghitung mean dan volatilitas dengan menggunakan persamaan (2) dan (3). Mean dan volatilitas dijadikan sebagai salah satu parameter untuk memprediksi curah hujan, adapun parameter lain yang di gunakan yakni dt dan nhari. Nhari merupakan banyak hari yang diprediksi. Bila stasiun 1 adalah stasiun Klimatologi Maros, stasiun 2 adalah stasiun Meteorologi Pongtiku, stasiun 3 adalah stasiun Meteorologi Andi Jemma dan stasiun 4 merupakan stasiun Geofisika Gowa maka parameter yang dibutuhkan untuk masing-masing stasiun ditunjukkan pada tabel (III)

Tabel III: Parameter Yang Digunakan Untuk Prediksi Curah Hujan Setiap Stasiun

\begin{tabular}{|l|l|l|l|l|}
\hline Parameter & Stasiun 1 & Stasiun 2 & Stasiun 3 & Stasiun 4 \\
\hline nhari & 1461 & 1461 & 1461 & 1461 \\
\hline $\mathrm{dt}$ & $\frac{1}{1461}$ & $\frac{1}{1461}$ & $\frac{1}{1461}$ & $\frac{1}{1461}$ \\
\hline$\sigma$ & 0.1227 & 0.1271 & 0.1225 & 0.0884 \\
\hline$\mu$ & 0.0708 & 0.0899 & 0.0812 & 0.0429 \\
\hline
\end{tabular}


Dari Hasil running sebanyak 10, 50, 100, 150 dan 200 iterasi, maka didapatkan hasil prediksi yang berbeda-beda adapun gambar (5) merupakan hasil plot prediksi pada setiap stasiun yang dibandingkan dengan plot data asli curah hujan pada setiap stasiun.

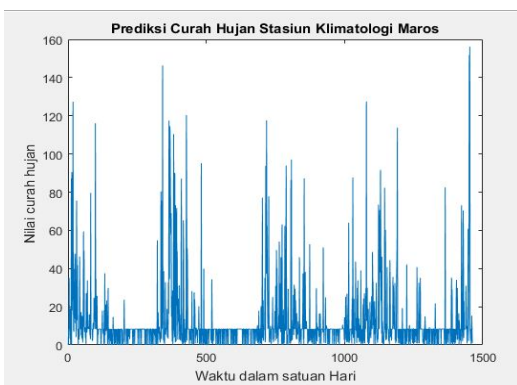

(a)

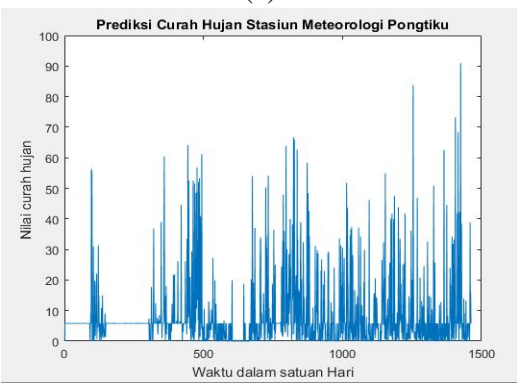

(c)

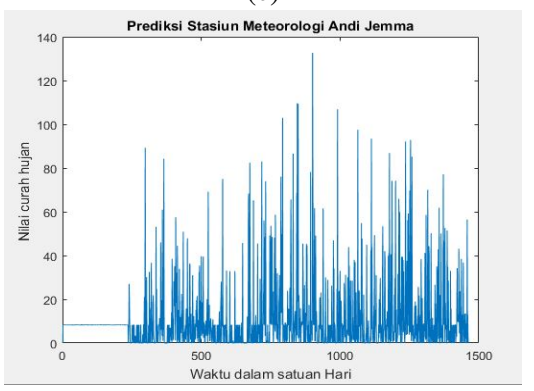

(e)

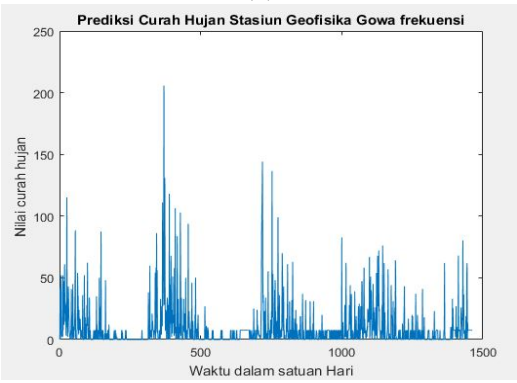

(g)

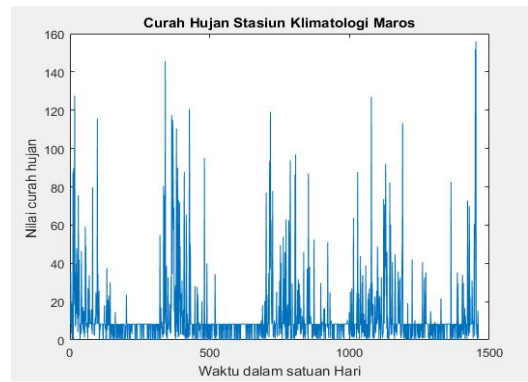

(b)

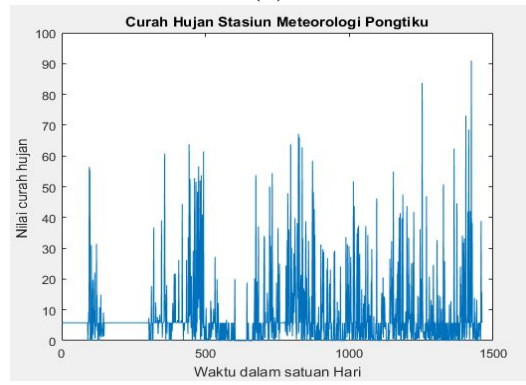

(d)

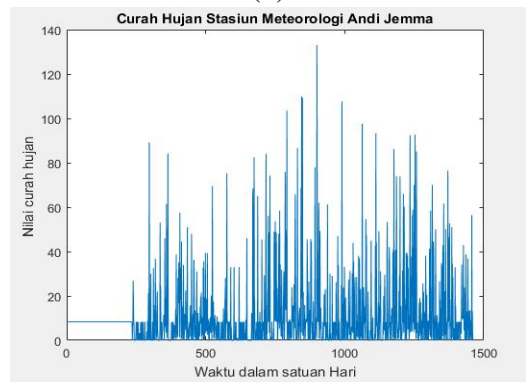

(f)

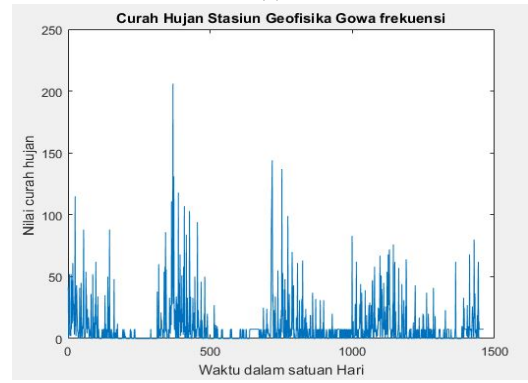

(h)

Gambar 5: Prediksi dan Data Asli Curah Hujan Pada Semua Stasiun. Gambar (5a) adalah prediksi curah hujan stasiun Klimatologi Maros, gambar (5b) adalah data asli hujan stasiun Klimatologi Maros, gambar (5c) adalah Prediksi curah hujan stasiun Meteorologi Pongtiku, gambar (5d) adalah data asli curah hujan stasiun Meteorologi Pongtiku, gambar (5e) adalah prediksi curah hujan stasiun Meteorologi Andi Jemma, gambar (5f) adalah data asli curah hujan stasiun Meteorologi Andi Jemma, gambar (5g) adalah prediksi curah hujan Stasiun Geofisika Gowa, gambar (5h) adalah data asli curah hujan Stasiun Geofisika Gowa 
Nur Nining A. ET.AL.

Prediksi Curah Hujan menggunakan...

Untuk gambar (5a) hasil prediksi memiliki trend data naik sebanyak 5 dan hasil prediksi curah hujan nilai minimumnya yakni 0.0009901 dan nilai maksimum adalah 156,5 . Sedangkan, untuk data curah hujan asli pada gambar (5b) trend data naik sebanyak 5 dan memiliki nilai minimum dan maksimum yang sama yakni 0.0001 dan 156. Hal ini membuktikan bahwa hasil prediksi curah hujan mengikuti data curah hujan asli. Sama seperti Stasiun Klimatologi Maros untuk stasiun Meteorologi Pongtiku, stasiun Meteorologi Andi Jemma dan stasiun Geofisika Gowa memiliki hasil prediksi yang mengikuti data curah hujan yang asli.

Pada gambar (5) hasil prediksi curah hujan kemudian digunakan untuk menghitung nilai RMSE dengan menggunakan persamaan (10), sehingga diperoleh nilai RMSE pada masing-masing stasiun. Jika Stasiun 1 merupakan RMSE dari stasiun Klimatologi Maros, stasiun 2 merupakan RMSE stasiun Meteorologi Pongtiku, Stasiun 3 adalah RMSE stasiun Meteorologi Andi Jemma dan Stasiun 4 adalah RMSE dari stasiun Geofisika Gowa.

Tabel IV: RMSE Prediksi Curah Hujan Setiap Stasiun

\begin{tabular}{|l|l|l|l|l|}
\hline Iterasi & Stasiun 1 & Stasiun 2 & Stasiun 3 & Stasiun 4 \\
\hline 10 & 21.9518 & 14.7606 & 21.6003 & 20.8582 \\
\hline 50 & 21.9494 & 14.7565 & 21.6015 & 20.8557 \\
\hline 100 & 21.9491 & 14.7512 & 21.6 & 20.8624 \\
\hline 150 & 21.9439 & 14.7544 & 21.5999 & 20.8526 \\
\hline 200 & 21.942 & 14.7538 & 21.5984 & 20.8515 \\
\hline
\end{tabular}

Untuk tabel (IV) semakin banyak melakukan percobaan maka hasil dari RMSE semakin kecil dan juga tabel bila diamati dari besar RMSE pada stasiun 1, stasiun 2 dan stasiun 3 besar RMSE mengikuti banyaknya missing value. Semakin banyak missing value data maka semakin besar RMSE yang diperoleh akan tetapi pada stasiun 2 memiliki jumlah missing value lebih besar dibandingkan stasiun 3 dan stasiun 4 tetapi nilai RMSE yang diperoleh lebih kecil. Hal ini disebabkan karena pada tahun 2014 stasiun 2 tidak memiliki data, sehingga untuk mengisi nilai missing value diambil dari data rata-rata tahun 2015, yang mengakibatkan nilai missing value pada tahun 2014 memiliki nilai yang sama pada setiap hari dalam satu bulan, maka mengakibatkan hasil prediksi mendekati nilai data aktual. Semakin banyak Iterasi yang dilakukan maka semakin kecil nilai RMSE yang diperoleh. Bila melihat nilai maksimum dan minimum dari tabel (II), maka hasil RMSE yang diperoleh cukup kecil.

\section{KESIMPULAN}

Berdasarkan hasil analisis dan pembahasan, maka didapatkan kesimpulan sebagai berikut :

1) Nilai mean dan volatilitas pada data yang telah di normalisasi serta $c h_{\text {old }(i-1)}$ dan $d t$ merupakan parameter yang dibutuhkan untuk memprediksi curah hujan menggunakan Metode Monte Carlo dengan Gerak Brown. Prediksi curah hujan dilakukan dengan menggunakan data histori t-1. Misalnya untuk memprediksi curah hujan pada tanggal 2 Januari 2014 maka menggunakan data asli pada tanggal 1 Januari 2014. Prediksi dilakukan pada tanggal 2 Januari 2014 hingga 31 Desember 2017. Hasil dari prediksi curah hujan pada iterasi-200 pada stasiun Klimatologi Maros, stasiun Meteorologi Pongtiku, stasiun Meteorologi Andi Jemma dan stasiun Geofisika Gowa memiliki nilai maksimum yaitu 156.5, 90.9, 133.2 dan 206.3 serta nilai minimum yakni 0.0009901, 0.0009913, 0.000992 dan 0.0009914 pada masing-masing stasiun secara berurutan.

2) Banyak missing value pada data mempengaruhi hasil prediksi curah hujan. Pada iterasi-200 dengan menggunakan persamaan (10) untuk data yang memiliki missing value yang besar memiliki nilai RMSE sebesar 21.942 sedangkan untuk data yang memiliki missing value yang kecil nilai RMSE yakni 20.8515 . 


\section{PUSTAKA}

[1] Takeshi F Andoh, Jessie Lindsley, Nora Franceschini, and William M Bennett. Synergistic effects of cyclosporine and rapamycin in a chronic nephrotoxicity model1. Transplantation, 62(3):311-316, 1996.

[2] Syaeful Arief and Taufiq Aji. Pengendalian persediaan menggunakan simulasi berbasis spreadsheet. Jurnal). Program Study Teknologi Industri, Fakultas Sains dan Teknologi, Universitas Islam Negri Sunan Kalijaga, Yogyakarta, 2013.

[3] Alex J Cannon and Ian G McKendry. A graphical sensitivity analysis for statistical climate models: application to indian monsoon rainfall prediction by artificial neural networks and multiple linear regression models. International Journal of Climatology, 22(13):1687-1708, 2002.

[4] Abdelmoula Dmouj. Stock price modelling: Theory and practice. Masters Degree Thesis, Vrije Universiteit, 2006.

[5] Rahmad Fauzi. Pengantar peramalan dalam telekomunikasi. 2004.

[6] Paul Glasserman. Monte Carlo methods in financial engineering, volume 53. Springer Science \& Business Media, 2013.

[7] Noviandhini Puji Gumati. APLIKASI METODE MONTE CARLO PADA PENENTUAN HARGA OPSI AMERIKA. PhD thesis, Universitas Pendidikan Indonesia, 2013.

[8] Sri Herawati. Peramalan harga saham menggunakan integrasi empirical mode decomposition dan jaringan syaraf tiruan. Jurnal Ilmiah Mikrotek, 1(1):23-28, 2013.

[9] Peter Jäckel. Monte Carlo methods in finance. J. Wiley, 2002.

[10] Kin C Luk, James E Ball, and Ashish Sharma. An application of artificial neural networks for rainfall forecasting. Mathematical and Computer modelling, 33(6-7):683-693, 2001.

[11] Anie Lusiani and Endang Habinuddin. Pemodelan autoregressive integrated moving average (arima) curah hujan di kota bandung. SIGMA-Mu, 3(2):9-25, 2011.

[12] Peter Mörters and Yuval Peres. Brownian motion, volume 30. Cambridge University Press, 2010.

[13] Kurnia Harja Mulyana. Prediksi nilai opsi beli menggunakan metode monte carlo dengan gerak brown, 2017.

[14] DMB Prihantoro et al. Pengujian Efisiensi Pasar Modal Indonesia Bentuk Lemah di BEJ Periode 1998-1999. PhD thesis, Program Pascasarjana Universitas Diponegoro, 2001.

[15] Ronald W Shonkwiler and Franklin Mendivil. Explorations in Monte Carlo Methods. Springer Science \& Business Media, 2009.

[16] Bambang Susanto. Gerak brown geometrik suatu tinjauan ulang. 2012.

[17] Ervin Yohannes, Wayan Firdaus Mahmudy, and Asyrofa Rahmi. Penentuan upah minimum kota berdasarkan tingkat inflasi menggunakan backpropagation neural network (bpnn). Jurnal Teknologi Informasi dan Ilmu Komputer, 2(1):34-40, 2015. 
